\title{
Loving God, loving me, loving others, and loving the environment: a sustainability education for elementary school children
}

\author{
Julia Suleeman ${ }^{1, *}$ and Jeny Tarigan ${ }^{1}$ \\ ${ }^{1}$ Faculty of Psychology Universitas Indonesia, Kampus UI Depok, Jawa Barat 16424, Indonesia
}

\begin{abstract}
This paper shows how sustainability education has been embedded as essential part of character development in one Christian school in Klaten, Jawa Tengah since the early 2000s. This has taken place as camps in the school area or live-in experiences in neighboring villages. Gradually, a more formal program as classroom lesson plans were deemed as important until one specific day was then devoted each week for this character development program. To serve this purpose, a general theme of love was chosen that was reflected in loving God, loving oneself, loving others, and loving the enviroment. From here, nine characters were chosen and used to be developed in each grade, from Grade 1 to Grade 6 . These nine characters are loving God, compassion, responsibility, self-control, discipline, critical, positive, creative, and efficient. The barriers faced by the school staff and school boards in running this program were regarded as challenges to improve this important program. More importantly, parents are also supportive and acknowledging the advantages of having this program for the holistic development of their children.
\end{abstract}

\section{Introduction}

As with other skills that are perceived as important, skills that support for the practices of sustainability should be implanted early in life.[1]. The importance of sustainability understanding and practices will not be applied in daily life if a child is let free to do on his/her own. Instead, family and school as immediate environment that a child has in life should work together in guiding the child to have the needed understanding and training. [2].

The claim that school is not only a place for intelectual exercising, but also where affective development is encouraged has long been accepted.[3, 4]. The schoolboard, the principle and several teachers of an elementary Christian school in Klaten, Central Java (located $17 \mathrm{~km}$ from Yogyakarta) took this claim seriously by arranging some extracurricular activities specifically for the character development of their students.

Starting in the year 2001, the students were taken to a nearby village to stay for two nights with the villagers. During their stay, they should not be treated as guests, but as the family members. And as family members they should be involved in house chores and

\footnotetext{
* Corresponding author: julia.suleeman@ui.ac.id
} 
should learn about the family background, like what the profession of the parents and their children, what the ups and downs the family has gone through, etc. Some of the host families are not sharing the same Christian faith. So it provides ample opportunity to build tolerance by respecting each other's faith and rituals.

\section{Methods}

The character program was made possible after a series of discussion and analyses that involved Board of School Committee, School Principal and the teachers, and finally the consultants. The process started in the year 2011 and until now the program is evaluated and updated. The flow chart below outlines the steps taken in the process of building and applying the character program.

\begin{tabular}{|c|c|c|c|c|}
\hline Year 2010-2012: & & Year 2012-2014: & Year 2014 - 2016: & Year 2016 - now: \\
\hline $\begin{array}{l}\text { School Committee, } \\
\text { School Chaplain, } \\
\text { School Principal } \\
\text { and teachers } \\
\text { discussed the } \\
\text { character program }\end{array}$ & $\Rightarrow$ & $\begin{array}{l}\text { School Chaplain, } \\
\text { School Principal, } \\
\text { teachers and } \\
\text { consultants } \\
\text { discussed the details } \\
\text { of the character } \\
\text { program }\end{array}$ & $\begin{array}{l}\text { Curriculum team } \\
\text { (School Chaiplain, } \\
\text { School Principal, } \\
\text { several teachers and } \\
\text { Consultants) wrote } \\
\text { and edited the } \\
\text { character curriculum }\end{array}$ & $\begin{array}{l}\text { Curriculum team } \\
\text { monitores, } \\
\text { evaluates and } \\
\text { revises the } \\
\text { character } \\
\text { curriculum }\end{array}$ \\
\hline
\end{tabular}

Recently, the School Committee and the Curriculum team held several meetings with representatives of the students' parents where it was agreed that the character program for parents would also be needed so that parents would be able to give their full support for the sucesscul of this program.

\section{The character development program}

Starting from the year 2012, the school decided to give a more formal curriculum on character development, resulting in a weekly meeting of 3 to 3.5 hours on character development lesson. This paper shows how the character development program was designed from Grade 1 until Grade 6. Several assumptions are used and they are as the following $[6,7]$.

The character to be developed is the one that reflects Jesus Christ' teaching on being a child of God. As a Christian school, the Christian values should be clearly understood and practiced in daily life. The program should integrate four subjects in discussion: God, self, others, and environment. It means that the character to be developed is on how we should act toward God, toward ourself, toward other people, and toward environment. These four parties should always be in harmonious relationship with each other. The biblical verses used to build the character development program are provided below (see Table 1).

Altogether nine characters are perceived as reflecting the Christian values. They are loving God, compassion, responsibility, self-control, discipline, critical, positive, creative, and efficient or practical. More information about these nine characters is provided below. The curriculum should be built up continuously and progressively so that all intended characters are discussed in each grade. The character program meets weekly for 180 minutes (for Grade 1,2,3, and 4) or 210 minutes (for Grade 5 and 6). For each academic year, the total meetings for the character program are 30, divided into two semesters. First semester is from the first week of August until the first week of December for a total of 16 
meetings with two weeks in October are devoted each for mid-exam week and for outings. Second semester is from second week of January until first week of May for a total of 14 meetings with one week in March or April is a break for Easter week and one week in March for mid-exam week.

The students should get engaged in this program happily. That students should enjoy what they learn at school or other learning situation in order to find meaning of what is being learned has long been emphasized.[5] That this has been achieved by the students can be observed when the school ends in the afternoon at 12.15. Not all students go home directly; around 20 students choose to stay and play with fellow students. They intentionally tell their parents who pick them up to give an hour or so to enjoy the school surroundings while playing with their friends.

School staff should be role models that demonstrating the desired character reflected in the relationship they build with the students and their parents, and among themselves[4]. The classroom teachers position themselves as a father or a mother for their students; they are usually alert in observing the students each day so when the students' negative emotion is shown the teachers would try to converse with them to find out what had disturb them. Each student who does not come to school for two consecutive days has a right to be visited by his/her classroom teacher. Therefore each of the classroom teachers keeps an updated list of their students' parents, both fathers or mothers. And since the kinship in Javanese culture is strong, it is not surprising that the teachers would also know the siblings of their students, their grandparents and other related members especially if they also come to school to pick the students up.

Parents should be supportive toward this program. In fact, it has been argued that parents are the first educators of moral principles for their own children [2, 5]. Therefore, the school must get parents and other concerned community members as "full partners in the character-building effort." [5]

A more detailed information about the biblical verses used to develop each subject is provided in Table below, together with examples of the activities run to support these subjects.

Table 1. Examples of bible verses and activities for loving God, loving oneself, loving others and loving the environment.

\begin{tabular}{|l|l|}
\hline $\begin{array}{l}\text { Example of } \\
\text { biblical verses } \\
\text { used }\end{array}$ & \multicolumn{1}{c|}{ Examples of activities } \\
\hline \multicolumn{2}{|c|}{ Loving God } \\
\hline $\begin{array}{l}\text { John 14:21; } \\
\text { I John 4: } 19\end{array}$ & $\begin{array}{l}\text { Loving God is nurtured in the beginning of each school day by } \\
\text { having a class devotion of 15 minutes consists of an opening prayer, } \\
\text { singing two worship songs, a reflection on a Biblical verse and a } \\
\text { closing prayer. At the end of the school day, another prayer is also } \\
\text { offered. Students even as young as Grade One take turn in leading } \\
\text { the prayers, and for Grade Two and above, also take turn in reading } \\
\text { the Biblical reflection. }\end{array}$ \\
\hline $\begin{array}{l}\text { Psalm 139: 13-15; } \\
\text { Matthew 22: 39; I } \\
\text { Corinthians 13: 4-8; }\end{array}$ & $\begin{array}{l}\text { Loving oneself is primarily expressed in how one should position } \\
\text { her/himself among other students. Teachers pay attention to how } \\
\text { each student in their class interact with each other. Often the teachers }\end{array}$ \\
\hline
\end{tabular}




\begin{tabular}{|c|c|}
\hline Ephesians 5: 29 & act as mediators if there are conflicts between the students. \\
\hline \multicolumn{2}{|r|}{ Loving others } \\
\hline $\begin{array}{l}\text { Matthew } 22: 39 \\
\text { Luke } 6: 27 \\
\text { John } 13: 34-35 \\
\text { Romans } 13: 8-10 \\
\text { I Peter } 4: 8\end{array}$ & $\begin{array}{l}\text { Bullying is not permitted. If one student gets bullied, the teachers } \\
\text { would call the aggressors and explain why bullying is not permitted. } \\
\text { When needed, several meetings are held between the involved } \\
\text { students, both the aggressors and the victim, until they interact well } \\
\text { again. In some cases, parents are also invited to talk to the students } \\
\text { involved. Usually this opportunity is used to strengthen the } \\
\text { relationship among school staff, students and their parents. Each } \\
\text { student also collects money for those in need and puts in him/her } \\
\text { own jar until it is time to collect them. If any of their gets sick, the } \\
\text { students are encouraged to visit the ill person while providing } \\
\text { encouraging words for him or her. }\end{array}$ \\
\hline \multicolumn{2}{|r|}{ Loving the environment } \\
\hline $\begin{array}{l}\text { Genesis } 2: 15 ; \\
\text { Exedus } 23: 10-11 \text {; } \\
\text { Leviticus } 25: 1-5 \text {; } \\
\text { Detereunomy } 12: 11- \\
12 \text {. }\end{array}$ & $\begin{array}{l}\text { Loving the environment is reflected in having a garden in the school } \\
\text { yard and each class takes turn in taking care of the plants. In addition } \\
\text { to that, there are also assignments where they need to identify if they } \\
\text { ever come across plants that they have not seen before. If they have } \\
\text { pets at home, they can share how they take good care of their pets, } \\
\text { what the habits of their pets, how they play with their pets, etc. }\end{array}$ \\
\hline
\end{tabular}

These four subjects of discussion are further developed into nine characters and each of these characters are also have sub-characters that are related. The nine characters and their sub-characters, including the example of activities done in class is as follow.

\section{- Loving God: worshipping God, fear of the Lord, avoiding sin, being thankful, being joyful}

Loving God refers to how we as child of God should love God with all our heart and with all our soul and with all your mind. (Matthew 22:37, NIV). How this is explained to the students is adjusted to their age. For Grade 1 and 2 students, for example, God is portrayed as the Creator who creates every creature and we should always come to God in wonder and in thanksgiving. For Grade 6 students, loving God should be a reason why we want to share to other people about what God has done in our love.

- Compassion: humble, caring, meek, caring for the earth and all creatures, caring for others, sacrificing

Compassion is having a pity toward other people in need, and is willing to help them (Ephesians 4:32). It is never too early to teach children about what compassion is. In fact, the school has a tradition since decades ago to maintain a harmonious relationship among the school staff, students, parents, and the neighbors. Teachers know where their students live and take notes of what kind of living arrangements they have. Some students live with their grandparents because their parents work in different cities. Knowledge of the students' familial background would help the teachers to understand the students and interact with them accordingly.

- Responsibility: accountable, trustworthy, honest, sincere 
Responsibility refers to do what one has to do, or been assigned to do (Matthew 25:21). In Grade 1, each student is reminded to prepare his/her school stuff with a minimum help from other family members. By the middle of semester one, the students should be able to do this independently so coming to school should not create any hassle. As part of responsibility character, honest and sincere are also discussed in Grade 1. Parents are encouraged to discuss with teachers, school principal or school counselor if as parents they find difficulty teaching these to their children. The students are expected to be good observers for their own surrounding and should report to teachers when they find suspicious activities or unusual events in their neighborhood.

- Self-control: patience, forgiving, tolerant, peace maker, cooperative and collaborative, non discriminative, independent.

Self-control is important to live among people of different ethnic, religion and social economic status. Using several bible verse such as 2 Corinthians 12 verse 6 and Galatians 5 verse 22-23, since Grade 1 the topic of diversity has been introduced to nurture self-control, forgiving and being tolerant.

- Discipline: orderly, healthy lifestyle, on time, keep promises, loyal, committed.

Discipline refers to willingly do according to what authority has ordered to (Colosians 2:5). The students are tolerated only 10 minutes late in the morning otherwise they should go home except for important matters like visiting the doctor. For healthy reason, the students can only buy food in school canteen even though there are several food sellers on the same street as the school.

- Critical: rational, analytical, reflective, decision making, being careful.

Being critical is not jumping into conclusion, but thinking clearly and orderly (Colosians $2: 8$ ). The students are encouraged not to be afraid to ask questions when they need to. There are opportunities when the students decide what activities they would like to engage when learning some topics.

- Being positive: motivated, optimistic, positive thinking, brave, good endurance, dare to try and make mistake, diligent, hard working, independent, being a role model. Being positive is having hope that God really takes good care of us (Matthew 6:25). Therefore, when a students looks unhappy, the classroom teacher would approach him or her to find out the reason and to offer help when needed.

\section{- Creative: innovative, having initiative, explorative, open for new things}

- Being creative is to think and to make something new (Genesis 1:1; Genesis 1: 27).

In Grade 2, students are guided to identify their talents and be proud of them. In Grade 6, students are first explained about multiple intelligence and undergo some exercises to identify how they perform in each of these intelligence. In Grade 3, students are asked to list ideas on how they could make their living environment look better.In Grade 5, the students should make a list of what mistakes people (including themselves) do so that their 
environment is ruined. They should also continue with ideas how to improve from those mistakes.

\section{- Efficient: practical, not consumptive, saving, simple.}

The school limits the amount of money the students can bring to school every day as their allowance. Since in every school break there are several teachers who are in charge to observe how the students eat or buy their food, those who bring a large amount of money are asked to explain the reason. Earth as created by God is a good place to start with, but humans might exploit the earth so some disasters can occur.

What is described as the character development program above is a result of three-year process where the curriculum team meet at least twice a month first to discuss the type of characters selected, the objective of each character in each grade, and the content of each meeting. The curriculum team consisted of the school chaplain, six teachers, two psychologists and two religious teachers. The barrier faced so far is that the school only has limited rooms to accomodate three parallel classes of each grade (altogether around 70 to 80 students) when they get together for the character program. The character program takes place on Saturday from 7.30 until 10.30 or 11 . The first hour is devoted as worship time for all students and this takes place in the school auditorium while the next hours the students get together with other students from the same grade.

\section{Conclusion}

For a character development program to be effective, several parties should collaborate and be in harmonious relationship among each other; these parties are school board, school staff, students, parents, and community. Each of the characters being developed should also being integrated in all school activities, and not only when the classroom discussion on that specific character takes place. Sustainability education for elementary school children should be implemented according to the school grade of the children while taking into account the living environment the children come from.

\section{References}

1. R. Alexander, Children, their world, their education. Final report and recommendations of the Cambridge Primary Review (2010).

2. T. Lickona, E. Schaps, C.C. Lewis, Eleven principles of effective character education. Character Education Partnership (2003).

3. M.H. Immordino-Yang, A. Damasio, Mind, brain, and education, 1, 3-10 (2007).

4. S.R. Kellert, Children \& nature: Psychological, sociocultural, \& evolutionary investigations 1, 117-151 (2002).

5. K, Olson, Wounded by school: Recapturing the joy in learning and standing up to old school culture (2015)

6. A. Lumpkin, J. Phys. Ed., Recr \& Dance, 79, 45-50 (2008).

7. M.W. Berkowitz, M.C. Bier, What works in character education : A research-driven guide for educators (Character Education Partnership, Washington, 2005) 